\title{
SORGHUM/MILLET MIXTURE AS AFFECTED BY CROP PROPORTION AND SORGHUM CULTIVAR IN A SEMI-ARID ENVIRONMENT
}

\author{
BIBINU A. T. S. , ISA A. and BWATANGLANG N.K. \\ Lake Chad Research Institute, P. M. B. 1293, Maiduguri, Nigeria
}

\begin{abstract}
Field experiment was conducted at the Lake Chad Research Institute Farm

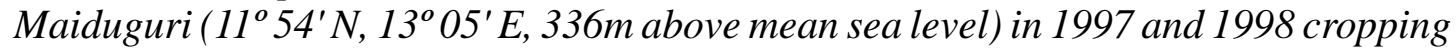
seasons to determine the productivity of Sorghum/Millet intercrop. Four sorghum cultivars (ICSV111, NR71182, NR71176 and ICSV400) and three crop proportions (1:1, 2:1 and 1:2 Sorghum/Millet) were compared in factorial combinations using a randomized complete block design. The study revealed that sorghum cultivar had no significant effect on millet plant height but significantly influenced sorghum plant height. Sorghum genotype ICSV111 matured significantly earlier than other cultivars in the mixture. Intercropping reduced sorghum and millet grain yield in both years. Sorghum cultivar ICSV111 produced the highest mean grain yield in the mixture. Crop proportion (1:2) Sorghum/Millet out yielded 1:1 and 2:1 Sorghum/Millet in terms of millet grain yield in both seasons. Both sorghum and millet grain yields increased significantly as their proportion in the mixture increased. The combination of sorghum cultivar NR71176 with millet produced the highest mean grain yield of millet. This is ideal for Sudan Savanna where the growing season is about 90 days. The highest land equivalent ratio of 49 and 60 percent were obtained at 2:1 and 1:2 crop proportions in 1997 and 1998, respectively.
\end{abstract}

Keywords: Sorghum, Millet, cultivars, semi-arid

\section{INTRODUCTION}

Grain sorghum (Sorghum bicolor L. Moench) and millet (Pennisetun glaucum (L.) R. Br.) are important cereal crops in Sudan and Sahelian Savanna Zones of Nigeria. These crops are commonly intercropped in the Savanna Region of Nigeria (Curtis, 1965). It is estimated that one-third to one-fourth of the grain production comes from fields planted solely to sorghum, the rest being from crop mixtures (Andrews, 1972; Elemo and Chobe, 1995) Gero millet has been a traditional crop in the agricultural system. Baker and Norman,1975; Yayock et al., 1988; Singh, 1993 reported that two crop mixtures predominate in the Savanna region more than three, four or more crop mixtures. Sorghum/Millet is the most popular system in the region (Norman, 1968; 1974).

Maturity difference (Andrews, 1972; Rao and Willey, 1983; Tsay et al., 1988 and Olufajo, 1995) and plant height (Wahua and Miller, 1978; Elmore and Jackobs, 1984) are known to exert great influence on the performance of component in a mixed cropping system. 
Recent breeding effort had resulted in the development of some high yielding sorghum genotypes. These genotypes have been developed under condition of sole cropping while most farmers cultivating sorghum grow their crops in mixtures. Therefore, there is need to evaluate the performance of these genotypes under intercropping conditions in the north east Nigeria.

This study was therefore designed to evaluate the productivity of sorghum/millet intercrop and to assess the effects of plant arrangement in the intercropping system.

\section{Experimental Site}

\section{MATERIALSAND METHODS}

Field experiment were conducted in 1997 and 1998 cropping season on the Lake Chad Research Institute Research Farm Maiduguri ( $11^{\circ} 54^{\prime} \mathrm{N}, 13^{\circ} 05^{\prime} \mathrm{E}$; $336 \mathrm{~m}$ above sea mean level). Maiduguri is a semi-arid town characterized by distinct annual long dry season ( 9 months or more) and short rainy season (3 months or less) with annual amount of rainfall in the range of 234-722 $\mathrm{mm}$ and a mean of $533 \mathrm{~mm}$ over the past ten years (Odo and Gwary, 1994). Relative humidity is usually low except at the peak of rainy season (July-August) and temperature is high during the growing season with monthly minimum and maximum of $23{ }^{\circ} \mathrm{C}$ and $33{ }^{\circ} \mathrm{C}$, respectively. The soils of the experimental site is sandy loam.

The experimental area was cleared and harrowed twice to a fine tilth and marked out into plots of $4.5 \mathrm{~m} \times 5.0 \mathrm{~m}$. The sorghum genotypes used were NR71182, NR71176, ICSV111 and ICSV400 while the millet genotype was Ex-Borno. These crop varieties are early maturing. The genotypes were developed at the institute for Agricultural Research Samaru, Zaria.

\section{Treatment and experimental design}

The treatments were made up of four sole crops of sorghum genotypes, a millet genotype and the 12 crop mixture treatments obtained by factorial combination of three crop proportions (1:1, 2:1 and 1:2 of sorghum: millet).Treatments were arranged in a randomized complete block design with three replications.

\section{Cultural and management practices}

Sorghum and millet were sown simultaneously on 26 June in 1997 and 9 July 1998 at 5 and 8 seeds per hole and later thinned to two seedlings per hill at 7-10 days after sowing (DAS). The component crops were intercropped in alternate row spaced at 0.75 $\mathrm{m}$ apart. In both sole and intercrops, the component crops were established at the recommended sole crop plant densities of 88,888 and 53,333 plants per hectare for sorghum and millet respectively; so that the total plant populations in intercrops were additive. Fertilizer was applied to all plots at the recommended rate of $30 \mathrm{Kg} \mathrm{N}, \mathrm{P}$ and $\mathrm{K}$ /ha as compound fertilizer 15:15:15 at sowing. The remaining half $\mathrm{N}$ dose $(30 \mathrm{Kg} \mathrm{N})$ was top dressed with urea at 6 WAS. Plots were hoe weeded at 3 and 6 WAS. 
Grain yield were determined from $5.0 \mathrm{~m}$ of the four central rows of each plot. The efficiency of the intercrop relative to monocrop was assessed by using the land Equivalent Ratio (LER) which is the proportional land area that would be required as sole crops to produce the yield achieved in intercropping (Willey, 1979). Data were taken per plot on plant heights, maturity and grain yield. Data were subjected to analysis of variance procedure appropriate for a randomized complete block design. The treatment means were compared using least significant difference (LSD) at 5\% level of probability when F-Values were significant (Gomez and Gomez, 1984).

\section{RESULTS AND DISCUSSION}

The effect of intercropping on sorghum and millet plant heights in 1997 and 1998 seasons are presented in Table 1. The results indicated that neither sorghum cultivar or crop proportion significantly influenced millet plant height in the mixture. For sorghum, the treatment effects on plant height were significant $(\mathrm{P}<0.05)$ in both years. Sorghum cultivar ICSV111 and NR71176 consistently produced the tallest and shortest plants respectively in both seasons. However, the difference between ICSV111 and NR71182 in 1998 was not significant (Table 1). Crop proportion 2:1 produced the tallest and the least heights in 1997 and 1998, respectively. The variation in plant height among the genotypes may be due to differences in genetic composition of the plant materials. It could also be attributed to differences in rainfall distribution between years. Similar findings were reported by Elemo and Chobe (1995) in a maize/sorghum mixture in northern guinea savanna.

There was significant variation among the genotypes on days to maturity (Table 1). Sorghum genotype ICSV111 consistently matured significantly earlier than the other genotypes in the mixture. Crop proportion had no significant effect on days to maturity except in 1998. The genotypes took significantly more days to mature at 1:2 crop proportion compared with either $1: 1$ or $2: 1$ crop proportions. The difference in days to maturity could be attributed to differences in genetic make-up of the materials as reported by Gworgwor (2001).

The effect of intercropping on sorghum and millet grain yields in 1997 and 1998 seasons are summarized in Table 2. The results, indicated significant $(\mathrm{P}<0.05)$ differences in the grain yields of both crops in 1997 and 1998 and when averaged over two years.

Millet yielded better in 1997 than in 1998. The highest grain yield of millet was recorded when intercropped with NR71176 in both year and when average over the two years (Table 2). Sorghum genotype ICSV111 consistently produced the highest mean grain yield in both years. Both grain yields of sorghum and millet increased significantly as their proportion in the mixture also increased. The reduction in the yield of millet in the mixture could be attributed to high rate of nutrient absorption. This supports similar observation made by Odo and Nanjwan (1999) and Bibinu and Odo (2005). It could also be due to difference in rainfall distribution between years. 
The Land equivalent ratio (LER) computed indicated that intercropping caused yield reduction in both 1997 and 1998. The highest reduction for sorghum was in 1998 compared with 1997. However, the combined LER of millet and sorghum intercrop exceeded the monocrop performance in both seasons (Table 3). Similar advantage of more effective land utilization has been reported with maize/sorghum (Elemo and Chobe, 1995). Results from the comparison of the mixture yield of the component crops with sole crops showed that increasing millet proportion in the mixture resulted in an increased in the LER of millet while the LER of sorghum decreased with increase in its proportion in 1997 but not consistent in 1998. Crop proportions 2:1 and 1:2 (sorghum: millet) produced the highest yield advantage of 49 and 60 percent in 1997 and 1998 respectively, reflecting superiority of this mixture to sole cropping of either millet or sorghum.

In conclusion, result of the study have shown that grain yields of both sorghum and millet increased significantly as their proportion in the mixture also increased. Sorghum genotype ICSV III consistently produced the highest mean grain yield in the mixture. Crop proportions 2:1 and 1:2 produced the highest yield advantage of 49 and 60 percent in 1997 and 1998 respectively. Thus, if a farmer gives priority to sorghum, the choice of 2:1 crop proportion is recommended whereas the interest is on millet grain, 1:2 crop proportion is suggested.

\section{ACKNOWLEDGEMENT}

The authors are grateful to Executive Director, Lake Chad Research Institute, Maiduguri, National Agricultural Research Project for providing the financial support and IAR, Samaru, Zaria for providing the sorghum materials used in the study.

\section{REFERENCES}

Andrews, D. J. 1972. Intercropping with sorghum in Nigeria. Experimental Agriculture 8: $130-150$.

Baker, E. F. I. and Norman, D. W. (1975). Cropping systems in northern Nigeria, In: Harwood, R. R. (ed.) proceedings of the cropping systems workshop held at the International Rice Research Institute, Loss Banos, Lagoons, Philippines, March 18-20, 1975, 334-361.

Bibinu, A.T.S. and Odo, P.E. (2005). Sorghum/groundnut intercropping as affected by nitrogen and phosphate fertilizers and groundnut population density in Semi-arid environment. Annals of Borno 21/22: 165-177. 
Curtis D. J. (1965). Sorghum in West Africa, Field Crops Abstract 18 (3): 145-152.

Elemo, K. A. and Chobe, S. M. (1995). Maize/Sorghum mixture as affected by crop proportion, stands arrangement and maize variety. Samaru Journal of Agric. Research 12: 67-76.

Elmore, R. W. and Jackobs, T. A. (1984). Yield and yield components of sorghum and soyabeans of varying plant heights when intercropped. Agronomy Journal $76: 561-564$.

Gomez, K. A. and Gomez, A. A. 1984. Statistical Procedures for Agricultural Research. $2^{\text {nd }}$ edition publisher: John Willey and Sons 680pp.

Gworgwor, N.A. (2001). Evaluation of pearl millet varieties for resistant to striga harmonthica. International sorghum and millet Newsletter 42: 85-87.

Norman, D. W. (1968). Why practice Intercropping? Samaru Agric. Newsletter 10 (6) $107-110$.

Norman, D. W. (1974). Rationalizing mixed cropping under indigenous conditions, the example of northern Nigeria. Journal of Development Studies 11 (6) 1-21.

Odo, P. E. and Gwary, D. M. (1994). Land use and cropping within Jerefadama in the Nigerian Sudan Savanna. In: Strategies for the sustainable use of fadama lands in northern Nigeria. A. Scones, L. Awogbade, M. O. and Voh, J. P. (eds.) CSER/ABU, (Zaria) and 11ED (London).

Odo, P.E. and Nanjwan, J.D. (1999). Nitrogen supplementation on pearl millet/groundnut intercropping system in a semi-arid environment. Journal of Arid Agriculture 9:21-28.

Olufajo, O. O. (1995). Orghum/Soyabean intercropping as affected by cultivar and plant arrangement in a sub-humid tropical environment. Samaru Journal of Agricultural Research 12: 3-11.

Rao, M. R. and Willey, R. W. (1983). Effect of genotype in Cereal/pigeon pea intercropping on the alfisols of the semi arid tropics of India. Experimental Agric. 19: 67-78.

Singh, B.B. (1993). Cowpea breeding Archival Report 1988-1992. Grain legume improvement Division. International Institute of Tropical Agriculture, 1993, Ibadan, Nigeria. 
Tsay, J. S.; Pukai, S. and Wilson, G.L. (1988). Intercropping cassava with soyabean cultivars of varying maturity. Field crop Research 19:211-225.

Wahua, T. A. T. and Miller, D. A. (1978). Relative yield totals and yield components of intercropping sorghum and soyabean. Agronomy Journal 70:287-291.

Willey, R. W. (1979). Intercropping its importance and research needs. Part 1. Competition and yield advantages. Part II. Agronomic relationships. Field Crops Abstracts 32 (1-10) 73-85.

Yayock, J. Y., Lombin, G. and Owonubi, J. J. 1988. Crop Science and Production in Warm Climates. London Macmillan, 307pp. 


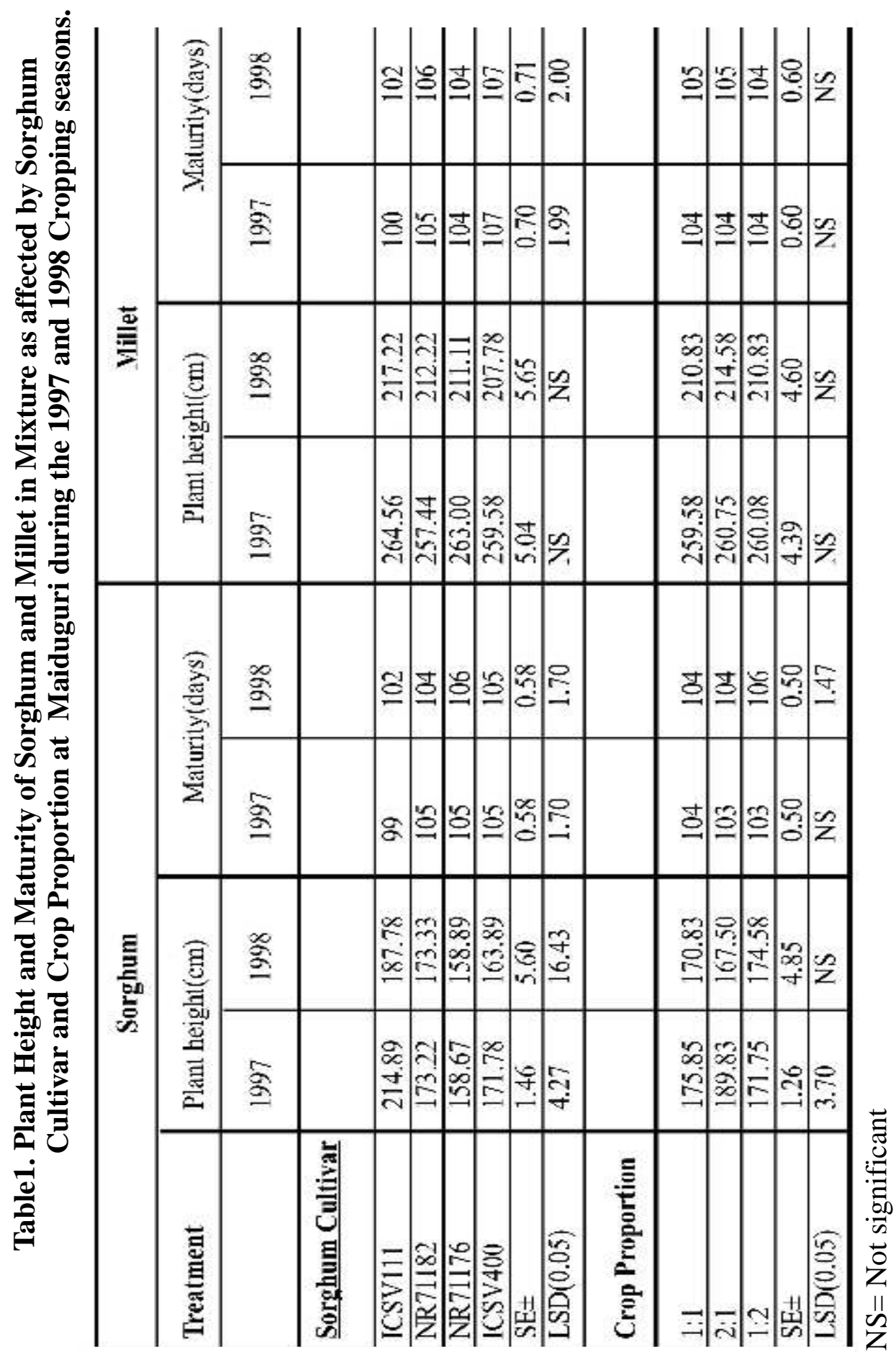




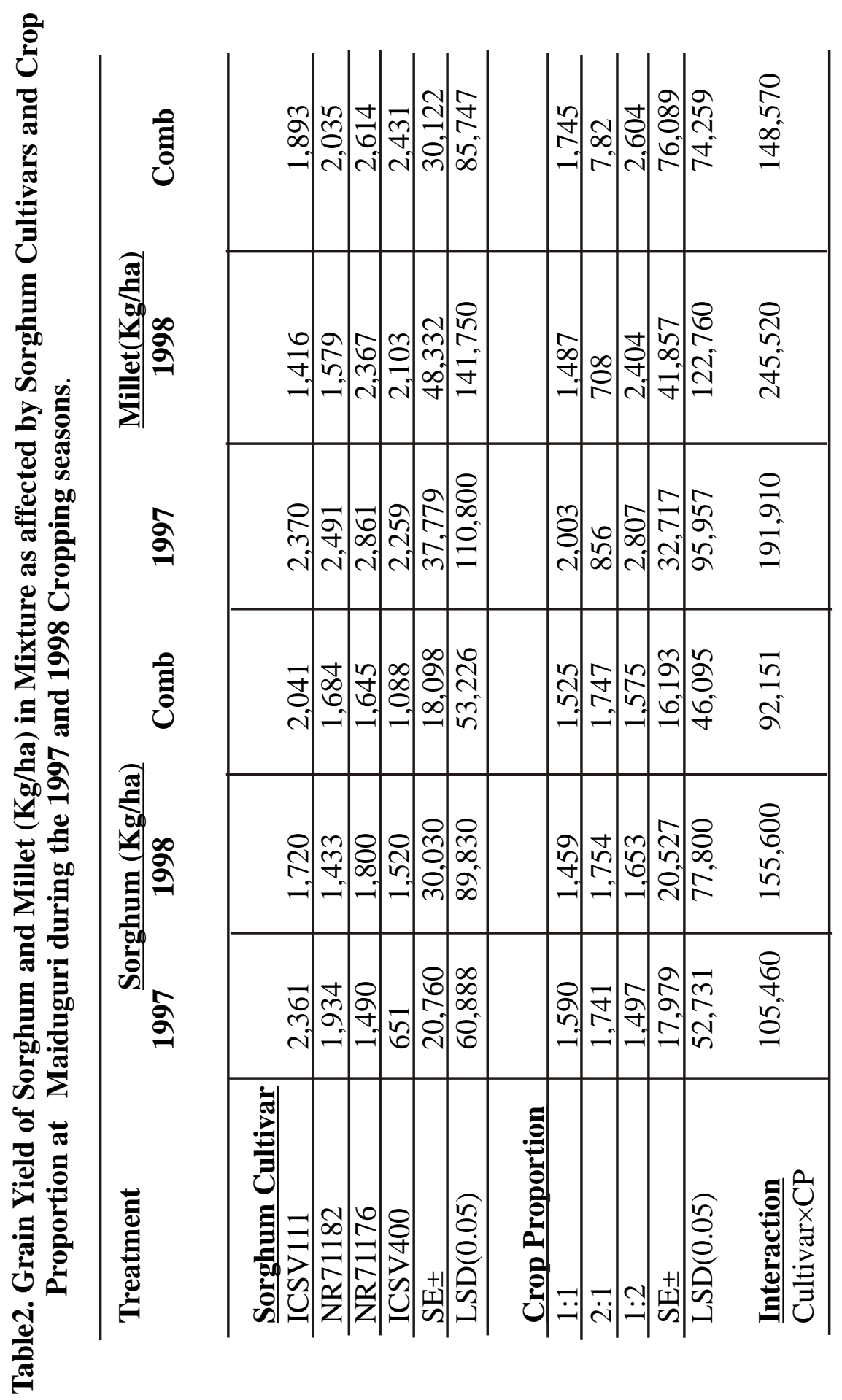




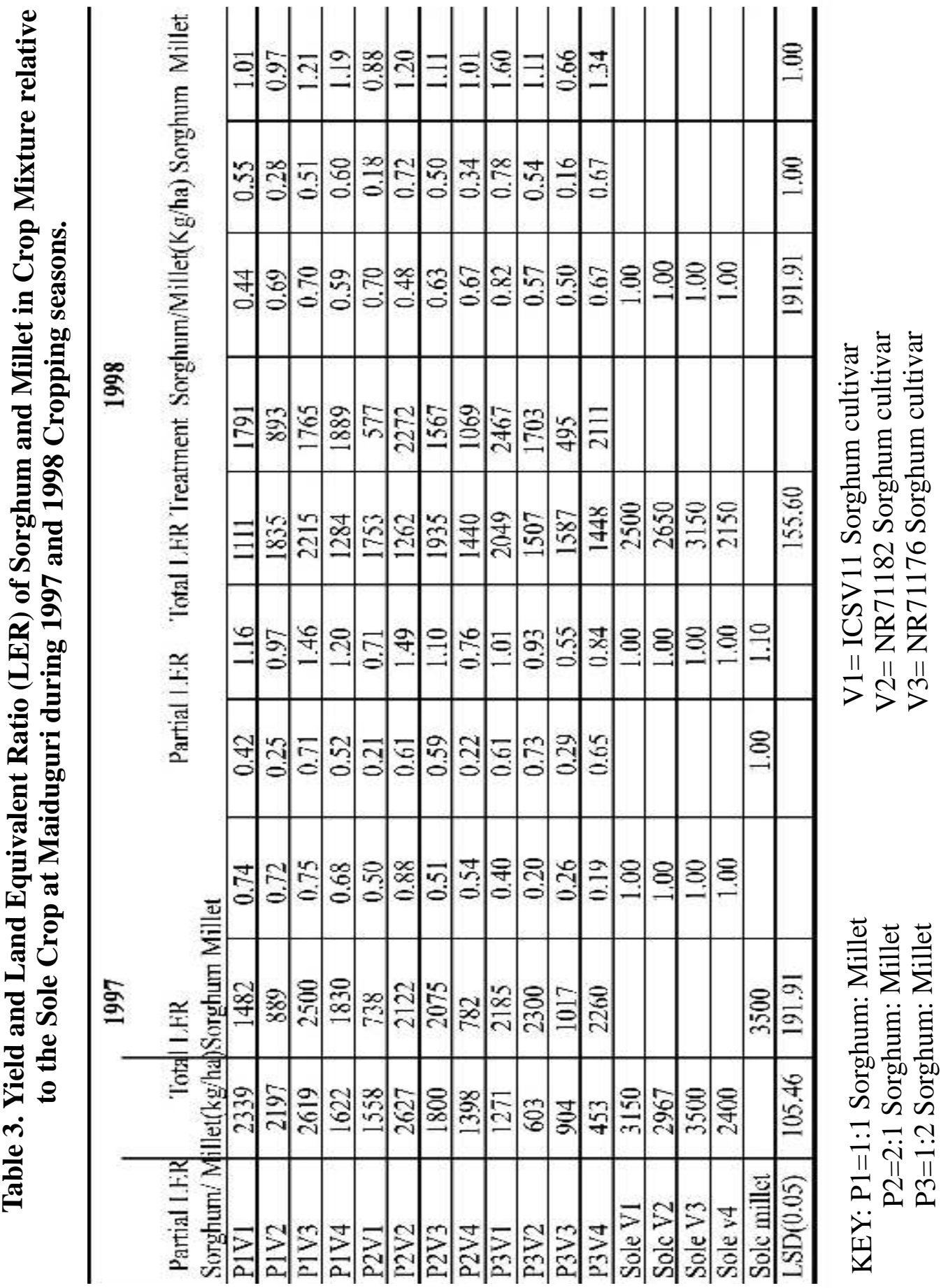

